\title{
Assessment of Water Quality of River Kalpathypuzha, Palakkad District, Kerala.
}

\author{
Divya.K.R* and K.Manonmani \\ P.G. and Research Department of Botany, Kongunadu Arts and Science College, Coimbatore 641029, Tamil \\ Nadu, India
}

\begin{abstract}
Water is an important element of the physical environment and a valuable resource with numerous and varied uses. Rivers are the primary source of water for drinking, irrigation and other domestic purposes. The present study has been undertaken to know the extent of effects of pollutants on the physicochemical characters and nutrient load of River Kalpathypuzha at Palakkad, where the River is grossly polluted. Three stations have been selected. All parameters were found to be the maximum in different station. Chemical parameters like $\mathrm{pH}, \mathrm{DO}_{2}, \mathrm{DCO}_{2}, \mathrm{BOD} \mathrm{COD}$ and total alkalinity were found to be more in Station III than in Station I and Station II respectively. Nutrients like calcium, magnesium, chloride, nitrate, sulphate, phosphate and silicate were analyzed.

Keywords: Water quality, Kalpathypuzha, Palakkad, Polluted, Alkalinity.
\end{abstract}

\section{Introduction}

Rivers are the most important components of global water cycle and have assumed greater significance in human survival on the background of emerging water crisis. It is high time that their role is to be properly evaluated in water economy of the country and effective actions to be initiated for their utilization and protection for common good.Agricultural wastes such as pesticides, fungicides, fertilizers, human and animal faces, seepage from pit latrines and septic tanks, refuge dump, industrial, domestic and all municipal wastes released into water bodies are often responsible for water contamination. Contaminated water is associated with health risks. It leads, to the spread of diseases such as dysentery, cholera, typhoid, diarrhea and so on. According to Grabow (1996) the associated with polluted water supplies include campbacteriosis, shigellosis, salmollosis, cholera and a varieties of other bacteria as well as fungi, viral and parasitic infection. The major proportion of all water quality degradation worldwide is due to antropogenic causes (Faniran et al., 1994). Biomonitoring of water bodies also help to understand the composition of biota and its dynamics (Scholl, 2010 and Grajner et al., 2011).This work presents the results of our field study which assessed seasonal changes in the physicochemical parameters and nutrient load of the River Kalpathypuzha, Palakkad district of Kerala.

\section{Materials And Methods}

Kerala is a land blessed with diverse, luxuriant habitat types, widely varying topography, high rainfall and large number of water bodies. Kerala receives generally the annual rainfall of $3000 \mathrm{~mm}$. Rivers are the veins of land with cultural, economic as well as ecological significance which regulate the surface flow of water.The river Kalpathypuzha starts from a place called chenthamarakulam in the hills, north of Walayar. Kalpathypuzha is formed by four streams-Korayar, Varattar, Walayar and Malampuzha. . Kalpathy is one of the well known gramams (villages) of Palakkad which is situated on the banks of the Kalpathy river. The place is famous for its agraharams (old Brahmin settlement), ratholsavam (temple car festival) and carnatic music. Another view regarding Kalpathy being linked to Kasi is that the main diety is lord Shiva and the temple on the banks of the River as Kasi, is on the banks of Ganges. The River water is used for domestic, small scale industries and agricultural purposes.

The river Kalpathy flows into Palakkad city and carries the pollutants from then and there. The river turns into the sewer for disposal of waste water from townships and rural communities. Water samples were collected for a period of six months (feb2009-july2009) from three stations respectively. The collections were made once in a month at the same time ie,7.30-8.30am and from same spots throughout the period of study. The samples were collected in a clean polythene container and brought to laboratory of Department of Botany, Kongunadu Arts and Science College, Coimbatore for further analysis. The samples collected were labelled properly and preserved at $4^{0} \mathrm{C}$ by refrigeration. The collection and analysis of samples had been done by Anonymous (1965). 
Table: 1 Methods followed for different parameters

\begin{tabular}{|c|l|l|}
\hline Sl.No & Parameters & Method followed \\
\hline 1 & Temperature & Thermometer \\
\hline 2 & colour & Visually \\
\hline 3 & Turbidity & Nepheloturbidity meter 132 \\
\hline 4 & Electrical Conductivity & EC meter,304 systronics \\
\hline 5 & $\mathrm{P}^{\mathrm{H}}$ & Digital $\mathrm{P}^{\mathrm{H}}$ meter \\
\hline 6 & Dissolved oxygen & Winklers method \\
\hline 7 & Total Alkalinity & APHA \\
\hline 8 & BOD & Winklers method \\
\hline 9 & COD & Open flux method \\
\hline 10 & chloride & Mohr's method \\
\hline 11 & phosphate & Colourimetric method $(650 \mathrm{~nm})$ \\
\hline 12 & Silicate & Colourimetric method $(420 \mathrm{~nm})$ \\
\hline 13 & Nitrate & Brucine sulphate acid method $(530 \mathrm{~nm})$ \\
\hline 14 & Sulphate & Turbidimetric method \\
\hline 15 & Calcium & EDTA method \\
\hline 16 & Magnesium & EDTA method \\
\hline
\end{tabular}

\section{Results and Discussion}

The study provides data on the physico-chemical parameters and nutrient load of the river water of Kalpathypuzha.In the present investigation, the colour of the water was light yellow throughout the period of study in station I, light brown at station II and colourless in station III. In station I, the temperature was ranging from $32{ }^{\circ} \mathrm{C}$ to $34{ }^{\circ} \mathrm{C}$. The maximum temperature of $34{ }^{\circ} \mathrm{C}$ during the month of March and April, 2009 and minimum of $32{ }^{\circ} \mathrm{C}$ in July, 2009 was recorded. In station II the maximum temperature was $34.2^{\circ} \mathrm{C}$ in April, 2009 and a minimum temperature was $32{ }^{\circ} \mathrm{C}$ in February and May, 2009. In station III the minimum temperature was $31.4^{\circ} \mathrm{C}$ in July, 2009 and maximum temperature of $33.2^{\circ} \mathrm{C}$ in April, 2009. Among all the ecological factors, the water temperature can be considered as an important factor on which the spawing in fishes depend.

A high content of dissolved solids elevates the density of water, influences the osmoregulation of fresh water organisms, reduced oxygen and water utility for drinking irrigational and industrial purposes. The values of total solids (suspended and dissolved) ranged between (900-1500 mg/l) in station I. Maximum value of 1500 $\mathrm{mg} / \mathrm{l}$ was recorded during February, 2009. Minimum value $900 \mathrm{mg} / \mathrm{l}$ was recorded during the month of May, 2009. In station II the maximum value of total solids was $100 \mathrm{mg} / \mathrm{l}$ for the month of April and June, 2009. In station III total solids ranged between $500 \mathrm{mg} / \mathrm{l}$ to $1200 \mathrm{mg} / \mathrm{l}$. The minimum value of $500 \mathrm{mg} / \mathrm{l}$ during the month of May, 2009 and maximum value of $1200 \mathrm{mg} / \mathrm{l}$ during the month of March and April, 2009 was recorded. Minimum conductivity has been recorded in station III (17.0 $\mu$ Mho). Conductivity of the samples gives rapid and practical estimate of the variation in dissolved mineral content of the water. The high EC values may be due to the addition of some salts from the agricultural practices. The lowest value of turbidity was noted in station I in the month of July 2009. Suspended and colloidal matter such as clay,silt,finely divided organic and inorganic matter, plankton and other microscopic organisms causes turbidity in water.

The $\mathrm{p}^{\mathrm{H}}$ values are ranged between 6 to 7.3 in station I, the minimum $\mathrm{p}^{\mathrm{H}}$ of 6 is showed during the month of February 2009 and maximum during May 2009. In station II the $\mathrm{p}^{\mathrm{H}}$ varies between 6 to 7.2. The maximum $\mathrm{p}^{\mathrm{H}}$ of 7.2 was showed in May 2009 and minimum $\mathrm{pH}$ of 6 was in February 2009. In station III the $\mathrm{p}^{\mathrm{H}}$ ranges from 5 to 6.9. The minimum $\mathrm{p}^{\mathrm{H}}$ was during the month of March 2009 and maximum 6.9 during July 2009. Aquatic organisms are affected by $\mathrm{P}^{\mathrm{H}}$ because most of their metabolic activities are $\mathrm{P}^{\mathrm{H}}$ dependent (Wang et al.,2002).Optimal $\mathrm{P}^{\mathrm{H}}$ range for sustainable aquatic life is 6.5-8.2 (Murdock et al.,2001).

There are two main sources of DO in water ie, diffusion from air and photosynthetic activity within water. Oxygen demanding waste like organic wastes causes rapid deletion of dissolved oxygen from water. Wastes decrease the dissolved oxygen. Maximum value of dissolved oxygen was found in station III when compared to station II and station I. The dissolved oxygen values ranges from 4.238 to $6.617 \mathrm{mg} / \mathrm{l}$ in station I, 4.314 to $7.466 \mathrm{mg} / \mathrm{l}$ in station II, 4.110 to $7.721 \mathrm{mg} / \mathrm{l}$ in station III.

Free carbon dioxide is an extremely necessary constituent in an aquatic environment as described by Welch (1952). Free carbon dioxide in water occurs due to respiration of aquatic biota, decomposition of organic matters and also due to infiltration through the soil. Carbon dioxide is an important component of the buffer system which influences carbonate and bicarbonate concentration in water. Values of dissolved carbon dioxide in station I ranged from minimum value of $11.9 \mathrm{mg} / \mathrm{l}$ were recorded during the month of February, 2009 and maximum value of $17.1 \mathrm{mg} / \mathrm{l}$ during the month of July, 2009. In station II the maximum was in June 2009 as $18.2 \mathrm{mg} / \mathrm{l}$ and minimum on April, 2009 as $15.2 \mathrm{mg} / \mathrm{l}$. In station III the values ranges from $42.5 \mathrm{mg} / \mathrm{I}$ to 70.4 $\mathrm{mg} / \mathrm{l}$. The minimum value of $42.5 \mathrm{mg} / \mathrm{l}$ was recorded during the month of February, 2009 and $70.4 \mathrm{mg} / \mathrm{l}$ during July, 2009. 
BOD test is used to determine the pollution load of river water, the degree of pollution. The values of BOD ranged from $312 \mathrm{mg} / \mathrm{l}$ to $396 \mathrm{mg} / \mathrm{l}$ at station I, $340 \mathrm{mg} / \mathrm{l}$ to $392 \mathrm{mg} / \mathrm{l}$ at station II and $414 \mathrm{mg} / \mathrm{l}$ to $425 \mathrm{mg} / \mathrm{l}$ at station III. COD is a test for the determination of the total oxygen demand by organic materials present in the water. Maximum value of $1467 \mathrm{mg} / \mathrm{l}$ of COD was recorded in station III when compared to station I and station II. COD values ranges from $700 \mathrm{mg} / \mathrm{l}$ to $731 \mathrm{mg} / \mathrm{l}$ in station I, $1041 \mathrm{mg} / \mathrm{l}$ to $1133 \mathrm{mg} / \mathrm{l}$ at station II and $1406 \mathrm{mg} / \mathrm{l}$ to $1467 \mathrm{mg} / \mathrm{l}$ at station III.

Alkalinity of any water is mainly due to carbonates, bicarbonates and hydroxide. It is an index of nutrient status in a water body. The availability of carbon dioxide for primary productivity is related to alkalinity. According to Moyle (1949), water is body having total alkalinity above $50 \mathrm{mg} / \mathrm{l}$ can be considered productive. The total alkalinity values ranged between $52 \mathrm{mg} / \mathrm{l}$ to $55 \mathrm{mg} / \mathrm{l}$ in station $\mathrm{I}$. The maximum value was shown in the month of March, 2009 and minimum value was April, 2009. In station II the minimum value 59 $\mathrm{mg} / \mathrm{l}$ was shown in the month of February, 2009 and maximum value was $72 \mathrm{mg} / \mathrm{l}$ in the month of July 2009, where as in station III maximum value was $69 \mathrm{mg} / \mathrm{l}$ in April, 2009 and minimum value was $50 \mathrm{mg} / \mathrm{l}$ in February,

Calcium contributes to the hardness of water within the bicarbonate, forming temporal carbonate hardness and sulphate, chloride and nitrate forming temporal carbonate hardness (Twort and Dickson, 1994).2009. Maximum values of calcium was reported in February, 2009 as $855 \mathrm{mg} / \mathrm{l}$ and minimum value of 420 $\mathrm{mg} / \mathrm{l}$ in July 2009 at station I. Maximum value was in April, 2009 as $390 \mathrm{mg} / \mathrm{l}$ and minimum value of $340 \mathrm{mg} / \mathrm{l}$ in July, 2009 at station II and in station III the minimum value in April, 2009 as $326 \mathrm{mg} / \mathrm{l}$ and maximum value of 395mg/l shows in February, 2009.

The values of magnesium ranged from 2100 to $3290 \mathrm{mg} / \mathrm{l}$ at station I, 7400 to $1800 \mathrm{mg} / \mathrm{l}$ in station II and 650 to $1870 \mathrm{mg} / \mathrm{l}$ in station III. Maximum value of magnesium was observed in the month of July, 2009 at station I and minimum value was observed in the month of February, 2009 in station I. High concentration of magnesium proves to be diuretic and laxative which reduces the utility of water for domestic uses while a concentration above $500 \mathrm{mg} / \mathrm{l}$ imparts an unpleasant taste to water and renders it unfit for drinking.

The higher concentration of chloride is considered to be an indicator of pollution due to high organic waste of animal origin. The chloride value was found to be minimum in February, 2009 as $3041 \mathrm{mg} / \mathrm{l}$ and maximum in March 2009 as $3592 \mathrm{mg} / \mathrm{l}$ at station III. The maximum value was in February, 2009 as $3052 \mathrm{mg} / \mathrm{l}$ and maximum value as $3479 \mathrm{mg} / \mathrm{l}$ in March, 2009 in station II. In station I the maximum and minimum was $3148 \mathrm{mg} / \mathrm{l}$ and $3046 \mathrm{mg} / \mathrm{l}$ in March, 2009 and May 2009 respectively.

Phosphate is useful in determing whether the pollution is due to domestic sewage. The values of phosphate ranged from $19.99 \mathrm{mg} / \mathrm{l}$ to $47.02 \mathrm{mg} / \mathrm{l}$ in station I, $16.42 \mathrm{mg} / \mathrm{l}$ to $31.8 \mathrm{mg} / \mathrm{l}$ in station II, 18.27 to 43.21 $\mathrm{mg} / \mathrm{l}$ in station III.

Generally, water bodies polluted by organic matter exhibit higher values of nitrate. The nitrate values were found to be a minimum in February, 2009 as $91.91 \mathrm{mg} / \mathrm{l}$ and maximum in the month of July, 2009 as $105.28 \mathrm{mg} / \mathrm{l}$ at station I. In station II, values were found to a maximum in February, 2009 as $90.53 \mathrm{mg} / \mathrm{l}$ and minimum in July, 2009 as $105.28 \mathrm{mg} / \mathrm{l}$ and in station III the maximum value of $88.37 \mathrm{mg} / \mathrm{l}$ during the month of February, 2009 and minimum of $63.23 \mathrm{mg} / \mathrm{l}$ during April, 2009.

The sulphate is one of the important anion in natural water and produce cathartic effect upon human beings present in excess amount (Srinivas et al.,2002) .The sulphate value was found to maximum in May, 2009 as $450.82 \mathrm{mg} / \mathrm{l}$ and minimum in June, 2009 as $420.12 \mathrm{mg} / \mathrm{l}$ at station I. The maximum value in June, 2009 as $137.1 \mathrm{mg} / \mathrm{l}$ and minimum in May, 2009 was $120.0 \mathrm{mg} / \mathrm{l}$. In station III, the maximum value was $251.52 \mathrm{mg} / \mathrm{l}$ in March 2009 and minimum in June 2009 as $235.25 \mathrm{mg} / \mathrm{l}$.

The major source of desired silicate in the river in the weathering of rock materials in the catchement areas. The values of silicates ranged from 1.101 to $1.255 \mathrm{mg} / \mathrm{l}$ in station I, 1.019 to $1.171 \mathrm{mg} / \mathrm{l}$ in station II, 1.031 to $1.046 \mathrm{mg} / \mathrm{l}$ in station III. The maximum value of silicate was observed during the month of June 2009 in station I and minimum in station II in June 2009.

\section{Acknowledgement}

The authors are thankful to Dr.M. Aruchami.,Secretary and Principal Dr. T. Muraleeswari of Kongunadu Arts and Science College, Coimbatore for their constant encouragement and facilities provided.

\section{References}

[1]. Anonymous, 1965. Standard methods for examination of water and waste water . Amer. Publ.Hcl.Assoc.New York 765.

[2]. Faniran J A., Adeleke, B.B., oderinde R.A (1994): For cados Terminal integrated projects basel ine ecological studies. Commissioned by Shell petroleum development company of Nigeria.

[3]. Grabow A K (1996). Properties of ordinary water substance in all its phases, water vapour,waterand all the Ices. American chemical society Monogram no 81,New York, Reinhold publishing corp p.73

[4]. Irena Bielanska Grajner, Anna Cudak, Tomasz Mieczan (2011): Epiphytic rotifer abundance and Diversity in moss patches in blogs and fins in the polsie national park(eastern Poland ) Inter Review of hydrobiology, vol 96(1),29-38 
[5]. Karoly Scholl(2010): Spatial and temporarily diversity patterns of planktonic rotifer assemblages in water bodies of the flood plain gemenic (Dunadrava national park) Inter Review of Hydrobiology, Vol 95, 6, 450-460.

[6]. Moyle,J.B.1949. Some indices of lake productivity. Trans. Amer. Fish. Soc.76:322-334

[7]. Murdock T, Cheo M and O Laughlin K (2001). Streamkeepers field guide watershed inventory and stream monitoring methods Adopt- A-Stream foundation, Everett.W.A. 297

[8]. Srivastava, S. and P.R. Patil, 2002. Tapti River Water pollution by industrial wastes: A Statistical Approach. Nat. Env. \& Poll. Tech. 1(2): $279-283$

[9]. Twort A ,Dickson C A (1994). Elementary water supply engineering Vol.1

[10]. Wang W, Wang A, Chen L., Liu y and sun R(2002)., Effect of $\mathrm{P}^{\mathrm{H}}$ on survival . Phosphorus Concentration Adenylate energy charge and $\mathrm{Na}+\mathrm{K}+$ ATPase activities of penaeus chinensis osbeck juveniles, Aquatic Toxicology 60, 75-83.

[11]. Welch, T.S1952.Limnology, $2^{\text {nd }}$ Ed . Mc.Graw Hill Book Co. N.Y. 